\title{
Polish-Lithuanian Mercenaries in the Service of Jacob de la Gardie
}

\section{T. Bohun}

For citation: Bohun T. Polish-Lithuanian Mercenaries in the Service of Jacob de la Gardie. Vestnik of Saint Petersburg University. History, 2018, vol. 63, issue 3, pp. 718-728. https://doi.org/10.21638/11701/ spbu02.2018.303

In the early $17^{\text {th }}$ century during Swedish-Polish-Lithuanian Commonwealth war there were very few soldiers of the Swedish army that were originally subjects to Sigmund III. This uncommon situation occurred because of various reasons, most notably, the core character of the conflict which was caused not only by the dynastic quarrel between the Polish and Swedish line of Vasas but also by cultural, political and religious differences. As the war in Livonia continued, Polish public finance system proved itself more and more inadequate. That caused unpaid Polish-Lithuanian soldiers to form confederations in order to make the authorities pay overdue wages. This rouge soldiers' crisis was exacerbated by a new war between the Commonwealth of Poland and Russia (1609-1619), which increased the crime and banditry in the Commonwealth of Poland. The authorities were forced to form military units - partly from the soldiers participating in the confederates - that were sent across the eastern border. Interestingly, at the same time a number of Zaporozhian Cossacks and Polish cavalrymen joined the army of Jacob de la Gardie, which occupied the area of Great Novgorod. Troops led by Henryk Dembinski, Jaromir Plecki and Stanislaw Wolski were a part of Swedish fighting force but - as the author remarks - might also have been involved in a larger false flag operation planned by Lithuanian intelligence in order to undermine financial potential of Sweden. It is very possible that this operation was supervised by the Lithuanian hetman Jan Karol Chodkiewicz and/or by the starosta wieliski Aleksander Gosiewski.

Keywords: Polish-Lithuanian-Swedish-Russian relations in the early $17^{\text {th }}$ c., Polish-LithuanianSwedish war in Livonia, The Time of Troubles, Swedish occupation of Novgorod, Military confederations, Polish-Lithuanian mercenaries, Intelligence of the Grand Duchy of Lithuania.

\section{Польско-литовские наемники на службе у Якова Делагарди}

\section{Т. Бохун}

Для цитирования: Bohun T. Polish-Lithuanian Mercenaries in the Service of Jacob de la Gardie // Вестник Санкт-Петербургского университета. История. 2018. Т. 63. Вып. 3. С. 718-728. https:// doi.org/10.21638/11701/spbu02.2018.303

В начале XVII в., во время войны Речи Посполитой с Швецией в Ливонии, в шведской армии служили лишь несколько солдат, подданных Сигизмунда III. Эта ситуация

Tomasz Bohun - PhD, Editor in a monthly popular science history magazine "Mówią Wieki" (Centuries Speak), 3, Europian sq., Warsaw, 00-844, Poland; bohuntomasz@gmail.com

Томаш Бохун - PhD, редактор исторического журнала «Mówią Wieki», Польша, 00-844 Варшава, Европейская пл., 3; bohuntomasz@gmail.com

(c) Санкт-Петербургский государственный университет, 2018 
была в основном обусловлена династическим характером конфликта между польской и шведской линиями Ваза, а также культурными, политическими и религиозными различиями. Польско-литовская система налогообложения не смогла справиться с затяжным конфликтом в Ливонии. Это привело к тому, что неоплачиваемые польсколитовские солдаты, чтобы побудить власти выплатить задолженность, образовали военные конфедерации. Война между Польшей и Россией (1609-1619 гг.) углубила этот кризис. По данной причине в Речи Посполитой выросли преступность и бандитизм. Примером может служить рейд полка Яна Карвацкого на Волынь и ее частичное разрушение. Путь к решению проблемы состоял в том, чтобы сформировать воинские части для отправки за восточную границу, частично из солдат, входивших в такие конфедерации. Интересно, что в это время несколько полков запорожских казаков под командованием Прокотовского, Гжегожа Яницкого, Миколая Ясинского, Мачея Халаима, Андрея Наливайки, Хвостовца, Федора Бориспольца и хоругвей регулярной польско-литовской армии присоединились к армии Якоба Делагарди, оккупировавшей регион Великого Новгорода. Солдаты во главе с Хенриком Дембинским, Яромиром Плецким и Станиславом Вольским вошли в состав шведской армии, но, как указывает сам автор, это также могло быть частью более крупной операции под так называемым фальшивым флагом, запланированной литовской разведкой для нанесения ущерба финансовому потенциалу Швеции, которая, проиграв войну против Дании, оказалась на грани финансовой катастрофы. Очень возможно, что эта операция была организована литовским гетманом Яном Карлом Ходкевичем и/или старостой велижским Александром Госьевским. Статья подготовлена на основе неизвестных архивных материалов.

Ключевые слова: сношения между Речью Посполитой, Швецией и Россией в начале XVII в., война Речи Посполитой со Швецией в Ливонии, Смутное время, Шведская оккупация Новгорода, военные конфедерации, польско-литовские наемники, разведка Великого княжества Литовского.

Polish-Lithuanian "soldiers of fortune" were quite unusual in the Swedish army during the first two decades of the seventeenth century, at least in comparison with their western European counterparts. Admittedly, there were probably four infantry outfits consisting of Poles, Hungarians and Livonian Germans (who were also subjects to Sigismund III Vasa) fighting alongside the Swedes between 1603-1605: 144 soldiers, mostly Polish, served under Hans Vegesack [Feyzak], 194 under Pawel Stylicki [Påvfel Stillicken], 81 under Tiedeman Schro, and Michael Horvath led 113 men. They weren't volunteers, though, but rather captives and/or deserters ${ }^{1}$.

There were at least a couple of reasons behind this situation. Firstly, Sigismund's administration swiftly and decisively addressed the problem of desertions that had been acute earlier - during the Moldavian war of 1595-1600. In February and March of 1601 the parliament deliberated in Warsaw and passed a resolution entitled "About those who leave for foreign military formations". The act unequivocally banned subjects of the king from enlisting in foreign armies, especially Swedish one, "during the Livonian expe-

${ }^{1}$ Generalstaben. Sveriges krig 1611-1632. Vol. I (Danska och ryska krigen). Stockholm, 1936. S. 577; Regestr piechothny Węgrów i Polaków (1603) // Stockholm Riksarkivet (further - SRA). Krigshistoriska handlingar (further - Kh). Militaria (further - M). 1282; Mankell J. Uppgifter rörande svenska krigsmagtens styrka, sammansättning och fördelning sedan slutet af fëmtonhundratalet. Stockholm, 1865. Appendix. S. 11; Łopatecki K. "Disciplina militaris" w wojskach Rzeczypospolitej do połowy XVII wieku. Białystok, 2012. S. 457-458. 
dition" (durante hac expeditione Livonica) ${ }^{2}$. Secondly, one could assume that such a small number of Polish-Lithuanian volunteers might be linked to unusual characteristics of this conflict. The war in Livonia was not only a clash over the province but also a dynastic conflict. Arguments inside the dynasty and religious differences also came into play. Polish and Lithuanian soldiers, Catholic as well as Protestant and Orthodox, all associated the wellbeing of their country (Kingdom of Poland and the Grand Duchy of Lithuania) with Sigismund III. In other words, it was impossible for them to swear an allegiance, on the Bible, to Charles IX. Lastly, there was the problem of a language barrier. Most of Polish noble-born soldiers, with the exception of Livonians and Estonians, rarely spoke German, Swedish or even Latin. The situation with peasants serving in infantry was similar, but to a greater extent. Of course, Swedish high command wasn't especially concerned about it - having at its disposal battle-hardened and dependable western European and British mercenaries.

This changed in just a few years. During Livonian conflict Polish-Lithuanian armies were able to succeed in the field, most notably, in the battle of Kircholm (1605), but siege attempts and maintaining control of strongholds remained problematic for them. In addition, inadequate fiscal policy of the country soon led to withholding soldiers' wages. Unpaid military formations started forming military confederations and often left Livonia to wreak havoc on the estates belonging not only to the crown but also to the church and private citizens in the Grand Duchy of Lithuania and central and southeastern parts of the Kingdom of Poland ${ }^{3}$. During the Livonian war four such military unions came about, containing about 8400-8500 soldiers in total. In 1602, the confederation of Biały Kamień (Bialy Kamien) was formed out of 32 cavalry outfits, consisting of almost 3500 men strong, formerly serving under Great hetman of Poland Jan Zamoyski (due to the lack of money in both Lithuanian and Polish treasury he had to pay substantial wages to soldiers out of his own pocket - which seriously undermined his considerable fortune and was one of the reasons why he stepped down from the Livonian command). Field hetman of Lithuania Jan Karol Chodkiewicz who took over Zamoyski had similar problems. In 1603, eight cavalry outfits consisting of 1000 riders revolted and formed a confederation of Dorpat, and between 1605-1606 other 900-1000 soldiers joined the confederation known as "brzeska". Two more confederations formed over this long decade during the first phase of the Livonian war were: "grodzienska" in 1609-1610, consisting of 2075 soldiers, and "inflancka", consisting of 700-800 men strong4.

The real problem for the Polish-Lithuanian Commonwealth turned out to be a truly catastrophic aftermath of the first stage of the war with Russia that occurred between 1609-1612. At the turn of 1611-1612 another confederation was formed in response to overdue payment, from the members of Polish-Lithuanian garrison in Moscow and the late Jan Piotr Sapieha's regiment, which supported it. Soon another confederation was formed from the soldiers of the garrison defending Smolensk. Both unions totaled over 7000 people. These rebellious military units for two years had been raiding wealthy re-

2 Volumina Constitutionum. T. II (1550-1609), cz. 2 (1587-1609). Warszawa, 2008. S. 272.

3 Wimmer J. Wojsko i skarb Rzeczypospolitej u schyłku XVI i w pierwszej połowie XVII wieku // Studia i Materiały do Historii Wojskowości. 1968. T. XIV. S.18-24; Ciara M. Konfederacje wojskowe w Polsce w latach 1590-1610 // Ibid. 1988. T.XXXI. S. 68-80.

4 UrwanowiczJ. Wojskowe "sejmiki". Koła w wojsku RzeczypospolitejXVI-XVII wieku. Białystok, 1996. S. 92-93; Filipczak-Kocur A. Konfederacja grodzieńska wojska litewskiego w latach 1609-1610 // Pamiętnik Biblioteki Kórnickiej. 1981. Z.18. S. 175-198. 
gions of the country, for generations unaffected by the tragedies of war: Ukraina, Volyn, western provinces of Grand Duchy of Lithuania and also Kujawy (Kuyavia), Pomorze (Pomerania) and Prussia. Chaos and anarchy were only increased by the multitude of other demoralized military formations, which officially weren't "confederated". Under the circumstances the regiments of Zaporozhian Cossacks were especially fierce, probably because they, with the exception of a hundred strong, state funded, registered Cossacks, "lived" only on spoils of war and plunder 5 .

In 1613, the royal administration, in particular the highest Lithuanian officials Chancellor Lew Sapieha and Hetman Chodkiewicz, and local governments of noblemen (sejmiki) finally started to fight this scourge. Of course, trying to attack highly capable and organized military confederations was tantamount tilting at windmills. This adversary was too strong. But dispersed and demoralized veterans of the Russian Time of Troubles turned into bandits were a different story. The tactic used against them was fairy simple do not let them cross the border between Russia, the Kingdom of Poland and the Grand Duchy of Lithuania.

To achieve that new commanders, who were used to leading exactly such type of warriors, were employed. The best example would be Aleksander Lisowski. He had been previously convicted - by the verdict of the Sejm court - of infamy for inciting mutiny among unpaid military outfits in Livonia in 1604 and pardoned in 1611. Between 1608-1610 Lisowski was leading Cossacks in the service of False Dmitri II. In 1611-1612, he managed to recruit an impressive party of 2000 men, mostly Zaporozhian Cossacks, in Zavolotch. With this force, he was quite successful in harassing the Russians, and by reaching a local agreement with the governor of Pskov actually reduced their pressure on the border. It is interesting to note that while recruiting his soldiers Lisowski was able to enlist two English captains Thomas Lichfield and John Stanford ${ }^{6}$ right from under Jacob de la Gardie. Another example of this type of a new, canny commander may be Zachariasz Zarudzki, who, due to the magic of his family name (he was the brother of ataman Iwan Zarudzki - a big supporter of Maryna Mniszek's claims to the tsar's throne), was very popular with Cossacks.

Since 1612 Zaporozhian Cossacks had been also enlisting to serve Jacob de la Gardie, the governor of Novgorod. This was largely possible thanks to suspension of hostilities between the Commonwealth and Sweden signed by Aleksander Gosiewski and de la Gardie in 1611 (strenuous talks had been on since the turn of 1612, and in June 1614 the sides decided on a truce until September of $1616^{7}$ ) that included Swedish-occupied region of Novgorod. The Swedish commander couldn't count on any reinforcements as his country was entangled in a war with Denmark at the time, so he welcomed Cossacks' enlistments and was seeking their support himself, especially due to the problem of False Dmitri III,

${ }^{5}$ Michałek A. Zejście załogi polskiej z Kremla i konfederacja Cieklińskiego 1612-1614 // Teki Historyczne-Cahiers d'histoire-Historical papers. Vol.XV. London, 1966-1968. P. 113-142; Michałek A. Konfederacja wojska stołecznego pod regimentem imć Cieklińskiego Józefa // Ibid. Vol.XVI. London, 1969-1971. P. 166-210.

${ }^{6}$ Volumina Constitutionum. T.III (1611-1640). S. 1 (1611-1626). Warszawa, 2010. S.43; A. Gosevskii - A. Lisovskomu, Pokrov, 20.05.1613 // Stockholm Krigsarkivet. Gustav Adolfsverket. Avskriftsamlingen. II: C 3 (further - KrA GA.A.II: C 3); A.Lisovskii - R. Sesilu. Ex Castris ad Zavolotiam, 10.08.1611 // Elementa ad fontium editiones. Romae, 1962. Vol. VI (Res polonicae Iacobo I Angliae regnante conscriptae ex Archivis publicis Londoniarum). P. 108-109.

7 Generalstaben. Sveriges krig 1611-1632. Vol. II (Polska kriget). Stockholm, 1936. S.4-29. 
who had just captured Pskov and was even shortly backed by the first militia draft of Cossacks stationed near Moscow, which was giving him sleepless nights. De la Gardie was so troubled that he even suggested cooperating with Lisowski in fighting a burdensome usurper .However, we don't know if the Lithuanian colonel agreed ${ }^{8}$.

Eventually, at the turn of June 1612 False Dmitri III was overturned in Pskov and handed over to the leaders of the first militia. De la Gardie seized the moment, and with the support of Evert Horn`s forces captured Koporie (Kopor'e), Jama (Jamgorod), Gdov and Ivangorod between June and December, which Swedes had been trying to conquer since July of $1610^{9}$.

Probably three or four outfits of Zaporozhian Cossacks participated in this campaign under the command of captains Prokotowski, Grzegorz Janicki, Mikołaj Jasiński and Maciej Chalaim. Their letters to de la Gardie prove that they were recruited by Evert Horn at the end of June 1612. The terms were very generous - the payment per quarter was set at "18 zloty for each horse". Unfortunately, the governor of Novgorod wasn't a generous man and effectively lowered their wages to only 3 zloty per quarter ${ }^{10}$. It may sound harsh but de la Gardie had his reasons. Firstly, he was strapped for gold even to pay his own troops and western European mercenaries, and, secondly, Horn `s promises to Cossacks were unrealistic. The payment for Ukrainian Cossacks recruited for so to speak "special operations" at the time amounted to 15 florens or 15 red (golden coin) zloty per quarter ${ }^{11}$.

The story didn't end there, though. During the siege of Ivangorod Cossacks suffered heavy casualties, and even when Horn, undoubtedly, appreciating their sacrifices, doubled their pay up to the amount of 6 zloty, they still were dissatisfied. They complained to de la Gardie that "Russians ransacked their camp, injured or killed both men and horses and now many of them have to go on foot behind the army" and demanded a raise to 30 zloty for the next quarter ${ }^{12}$. During the period in question even the most elite cavalry units in the army of Commonwealth were paid less (hussars got 25 zloty per quarter ${ }^{13}$ ). So, it is easy to understand that ongoing collaboration between this group of Cossacks and de la Gardie was impossible.

Next, a more numerous group of Cossacks was enlisted into Swedish service in Russia in autumn 1612. In September, after the failed attempt to help Polish-Lithuanian garrison besieged in Moscow, regiments under Andrij Nalewajko (Andrii Nalevayko), Chwostowiec (Khvostovec) and Fiodor Boryszpolec (Fedor Boryspolec) (about 3500 men strong ${ }^{14}$ )

${ }^{8}$ Kordt B. Iz semeinogo arkhiva grafov De-la-Gardi. Ia. Delagardi - A.Lisovskomu. Novogrod, 23.01.1612 // Uchenye zapiski imperatorskogo Iur'evskogo universiteta. Vol.2. Iur'ev, 1894. Prilozhenie 2. P. 14-16; Pskovskie letopisi. Vol. V, iss. 1. Moscow, 2003. P.140; Zamiatin G. Rossiia i Shvetsiia v nachale XVII veka. Ocherki politicheskoi i voennoi istorii. St. Petersburg, 2008. P. 277-278.

9 Zamiatin G. Rossiia i Shvetsiia... S. 280-281; Dzh. Spens - R. Sesilu, Stokgolm, 30.09.1610 // The National Archives (Kew). State Papers 95-1 (Sweden). L. 170; Bohun T. Najemnicy z Wysp Brytyjskich w armii szwedzkiej na początku XVII wieku // Studia z dziejów stosunków Rzeczypospolitej z Państwem Moskiewskim w XVI-XVII wieku. Zabrze; Tarnowskie Góry, 2013. S. 116-147.

${ }_{10}$ M. Iasinskii i M. Khalaim — Ia. Delagardi, (?), 9.08.1612 // KrA. GA. A. II: C 3.

11 Bewisse Avise, die Ich Jürgen Sahm meiner haben den Instruction und besehens nach von dieser meiner Reise mitt gebrachn, Reval (?), after August 1615 // SRA. Kh. M. 1289.

12 M. Iasinskii i M. Khalaim - Ia. Delagardi, Szarkymy, 13.06.1612 // KrA. GA. A. II: C 3; M. Iasinskii i M. Khalaim - Ia. Delagardi, (?), 9.08.1612 // Ibid.

13 Bewisse Avise, die Ich Jürgen Sahm... // SRA. Kh. M. 1289.

14 Bohun T. Moskwa 1612.Warszawa, 2005. S. 190-242; Z dopitiv zaporos'kikh kozakiv, vziatikh v polon v boiu pid Olontsem, Moskva, mart 1614 // Dokumenti rosiis'kikh arkhiviv z istoriï Ukraïni. Vol. 1. 
left the army of Hetman Chodkiewicz to seek employment elsewhere. They were allowed to do so because the third quarter of their service had just ended. The Cossacks were stationed near Toropiec, which had been captured by Swedes, and awaited offers from recruiters. Lithuanian referendary Gosiewski tried to enlist them but he was outcompeted by Horn and de la Gardie who had made Cossacks an attractive offer six months earlier. They couldn't accept it then because of an outstanding contract with Hetman Chodkiewicz ${ }^{15}$. Now, after the election of high command (Nalewajko won again and for other regiments the Cossacks elected former sotniks Sidor and Trofimov colonels) they left for Novgorod where soldiers pledged allegiance to Gustav Adolf in an evangelical rite ${ }^{16}$.

In 1613 the governor of Novgorod found himself in very tough situation - Michael Romanov became Tsar in March. This meant not only the end of the dreams of installing Prince Charles Philip on the Moscow throne but also the beginning of troubles in his own dominion. The new Tsar was immediately accepted by yet unsubdued Pskov, and in May and at the turn of June and July Tichvin revolted and was captured by the armies of Siemion Prozorovski and governor (voyevoda) Leontii Veljaminov. The rebellion also broke out in Gdov (where Swedish deputy Volmar von Ungern was captured and put in prison in Pskov with the rest of the captives). Losing Tichvin was especially dangerous for de la Gardie because Russians could now disrupt the communication line between Novgorod and Staraya Ladoga (across the Volkhov river) ${ }^{17}$.

The Russians also took control over Viazma, Dorohobuz and Belaia (Biała). This endangered the garrison of Smolensk, and put the Commonwealth on the defensive. In these circumstances de la Gardie and Gosiewski came to an agreement not only to stay out of each other's way but actually to help each other if the situation on Lithuanian - Novgorod borderland required it. Lithuanian referendary put Cossacks under Sidor and Boryszpolec in this operation, but Nalewajko's regiment returned to Lithuania ${ }^{18}$, probably following orders issued by Gosiewski or Chodkiewicz.

About 1500 Zaporozhian Cossacks remained in the Swedish army. They were ordered to join the outfit of western European mercenaries, comprising 3000 men strong, under the command of Daniel Hepburn. Their goal was to retake Tichvin ${ }^{19}$.

The siege didn't take long - just about a month. Cossacks played a major role in taking not very well-fortified Vvedensky Monastery, but suffered heavy casualties in the failed assault on 7 September, and by 12 September 1613 had left the Swedish army. De la

Dokumenti do istoriï zaporoz'kogo kozatstva 1613-1629 rr. / eds L. Voitovich, L. Zaborovskii, Ia. Isa€vich, F. Sisin, A. Turilov, B. Floria. L'viv, 1998. P. 64-65.

15 A. Nalivaiko - Ia. Delagardi. Borowicze, 21.02.1612 // KrA. GA. A. II: C 3; M. Shirai - E. Gornu, Jewanow (?), 27.03.1612 // Ibid; Ia. Lukashevich - E. Gornu, Szorkowa Dolina z Słobody, 2.04.1612 // Ibid.

${ }^{16}$ Z dopitiv zaporos'kikh... S. 64-65; Sidor - Ia. Delagardi, (?), ianvar' 1613 // KrA. GA. A. II: C 3.

17 Zamiatin G. Rossiia i Shvetsiia... S. 284-285; Zamiatin G. "K Rossiiskomu tsarstviiu pristoiat". Bor'ba za osvobozhdenie russkikh gorodov, zakhvachennykh shvedami, v 1613-1614 gg. V. Novgorod, 2012. P. 58-74; Shaskol'skii I. Shvedskaia interventsiia v Karelii v nachale XVII v. Petrozavodsk, 1950. P. 108.

${ }^{18}$ Sidor - Ia. Delagardi, Iiun' 1613 (?) // KrA. GA. A. II: C 3; Z dopitiv... P. 64-65.

19 Rasprosnyia rechi cherkashenina Ileiki, Moscow, 19.12.1613 // Rossijskij godudarstvennij arhiv drevnikh aktov (RGADA). F. 210, Op. 9. D. 11. Stb. 3. L. 481-482; Rasprosnyia rechi cherkashenina, vziatago pod Kolmogorkim ostrogom pri pristupe, o chisle napadavshikh i imenakh nachal'nikov, Moskva, posle 8.10.1613 // Akty Moskovskogo Gosudarstva, izdannye Imperatorskoiu Akademiiu nauk / ed. by N. A. Popov. Vol. I. St. Petersburg, 1890. P. 82; Otpiska iaroslavskikh voevod Vasiliia Tiumenskago s tovarishchi ob otsylke v Moskvu kazakov Kuz'my Nevorova da Smirnogo Ivanova, vsledstvie obvineniia ikh v izmene, s prilozheniem rasprosnykh rechei, i dopros tekh kazakov v Moskve, Iaroslavl, posle 11.01.1614 // Ibid. P.9192; Zamiatin G. Rossiia i Shvetsiia... P.73-74. 
Gardie didn't intend to uphold his promise to pay them for the fourth quarter of the year, and heavy loses both of men and horses discouraged them from continuing their service there. That effectively ended the siege of Tichvin ${ }^{20}$. In the following months the regiments of Sidor and Boryszpolec operated in the Lake Onega region and on the shores of the White Sea but were unable to capture either Andomsky ostroshok or Kholmogory important strategic points on the trade route from Arkhangelsk to Moscow - defended by Russians supported by the British mercenaries under the command of Sir Arthur Aston. They also failed in capturing Sumsky Ostrog. Finally, Cossack regiments were defeated in the battle of Olonec ${ }^{21}$.

In 1614, the army of de la Gardie had three outfits of regular Polish-Lithuanian military at its disposal: one unit of hussars under Hieronim Dembiński and two more similar cavalry units called "petyhorcy" (the main difference between them and the hussars being their lighter armor) led by Jaromir Plecki and Stanisław Wolski. Their force totalled no more than 300 men. The scarcity of sources doesn't enable us to accurately present all aspects of their service in 1614-1615. An anonymous letter written by a group of officers from these units to de la Gardie suggests that they completed a full recruitment procedure involving the signing of the contract, whose details - the duration and monetary compensation remain unknown - and, more importantly, swearing to uphold the terms. Their pledge taken in accordance with the evangelical rite was received by Evert Horn instead of Gustav Adolf (his full titulature was mentioned in the document) ${ }^{22}$.

There is every indication to suggest that their contract was an effect of the agreement between Gosiewski and de la Gardie - mentioned earlier. It is worth noting that at the turn of December of 1614 this agreement also allowed the governor of Novgorod to give permission to Zachariasz Zarudzki's regiment to stay in Molvotritche, a settlement which is hard to be identified on the map, located to the north west of lake Ilmen) while it was preparing to cavalry run alongside the banks of the Volga River as far as Nizhnii Novgorod ${ }^{23}$.

At the beginning of 1615 Evert Horn attempted at capturing Pskov. The plan was to create a diversion in Tichvin area. This task was carried out by Samuel Cobron's men, while the other group: 200 Swedish and foreign mercenaries, outfits under Dembiński, Plecki and Wolski and Asmus Glazenap's and Jacob Duval's soldiers, about 700 men strong, led by Horn, Robert Moor and Paul Gottberg, assaulted the city trying to take it, or if that failed, to cut off their food supply and force it into submission. Polish-Lithuanian units under the high command of Dembiński were especially precious to Horn because he didn't have enough cavalry in his service. He also expected his plan to succeed because he

${ }^{20}$ Rasprosnyia rechi cherkashenina Ileiki, Moscow, 19.12.1613; Rasprosnyia rechi Antsa Shvarka (VIII), Belozero, 4.10.1613 // Dopolneniia k Aktam Istoricheskim sobranyia i izdanyia Arkheograficheskoiu Kommiseiu / eds Ia. Berednikov, M. Korkunov. Vol. II. St. Petersburg, 1846. P. 15; Zamiatin G. "K Rossiiskomu tsarstviiu pristoiat" ... P. 98-99; Kurbatov O. Tikhvinskoe osadnoe sidenie 1613 g. Moscow, 2006. P. 30-44.

${ }^{21}$ Shaskol'skii I. Shvedskaia interventsiia v Karelii... P. 108-112.

22 Anonim - Ia. Delagardi, Novgorod, 1614 // Tartu Ülikooli Raamatukogu (further - TÜR). F. 6:B. L. $111-111 \mathrm{ob}$.

${ }^{23}$ Z.Zarutskii - E. Gornu, Molwotrycze (Molvotrichi), 25.11.1614 // KrA. GA. A. II: C 3; Z gramoti, vruchenoï u Posol's'komu prikazi novgorods'kim poslam Ia. Boborikinu i M. Muraviovu, Moscow, 9.03.1615 // Dokumenti rosiis'kikh arkhiviv z istoriï Ukraïni. T. 1. L'viv, 1998. P. 78; Skobelkin O. Smuta i sud'by sluzhilykh "nemtsev" // Mininskie chteniia. Sbornik nauchnykh trudov po istorii Smutnogo vremeni v Rossii nachala XVII v. V pamiat' 400-letiia Nizhegorodskogo Podviga / eds A. Kuznetsov, A. Morokhin, O. Naumov. Nizhnii Novgorod, 2012. P. 245. 
had some conspirators within the city walls (recruited from "posadskiie ljudi" - residents of the bailey, probably merchants). Furthermore, Horn was awaiting reinforcements about 600 men under Jan Karwacki (Johann Carvatsky) ${ }^{24}$. On the other hand, food supply to Pskov was already controlled by Swedish forces at Porchov and Gdov (retaken in September of 1614) - cities to the north and east of the town. The only remaining open route was to the west through Izborsk until Livonia ${ }^{25}$.

Robert Moor's units, under the command of Horn at the time, arrived in Pskov at the second half of January 1615 but weren't able to seriously threaten the city. The conspirators detonated an explosive beneath the city walls but it failed to do anything more than a lot of noise. Their operation was also premature, being conducted even before the Swedish forces arrived. Governors of Pskov, Ivan Chovanski and Fiodor Buturlin, had little trouble in repairing whatever damage was done. Also, Horn's and Moor's forces didn't have any artillery or siege equipment at their disposal. They tried to assault the city on 25 January, but the attack was easily repelled. So, the blockade of Pskov began but, in spite of ensuring control of the route between Izborsk and Pskovo-Pechersky Monastery, brought about little effect ${ }^{26}$.

Karwacki, despite earlier promises, refused to back his efforts because of the inability to sufficiently supply his troops in this area, at least, according to Horn ${ }^{27}$. By the way, the decision not to join Moor might have been for the better because it allowed him to raid part of Volyn in April 1615. The bloody activities of Karwacki ended when his regiment was destroyed the next month by the regular Polish army led by Stanislaw Żółkiewski. Karwacki himself, as well as three chieftains of his "gang of bandits", was publicly executed in $\mathrm{Lvov}^{28}$.

Meanwhile, there emerged a conflict between Moor's outfits and Polish-Lithuanian troops, and Swedish soldiers and western European mercenaries. There were fights and dishonorable assaults, and, quite possibly, even duels. The root of the problem was, of course, money. Horn didn't pay Poles and Lithuanians their wages for the second quarter of 1615. Although he himself ensured Gustav Adolf that his hands were clean in this mater, his correspondence with Dembiński and Jan Kunowski presents another perspective. Dembiński also accused the Swedish commander of bias in dividing provisions, and breaking the agreement of 1614 (presently unknown to us), according to which Swedish King committed himself to recruit 4000 soldiers from the Commonwealth. In this situation Dembiński and his officers threatened to form a confederation and raid estates belonging to the Swedish crown (probably, Novgorod region) ${ }^{29}$. It was mostly an empty threat - 300 cavalrymen simply couldn't put the same amount of pressure on the Swedes as over a dozen thousands had done earlier on the Commonwealth's administration and

24 E. Gorn - Gustavu Adol'fu, Novgorod, 27.04.1615 / Arsen'ev V. Arsen'evskie shvedskie bumagi. Vol. 1 (1611-1615 gg.) // Sbornik Novgorodskogo obshchestva liubitelei drevnostei. Iss. 5. Novgorod, 1911. P. 52; Zamiatin G. Rossiia i Shvetsiia... P. 307-309.

25 Zamiatin G. Rossiia i Shvetsiia... P. 307-309.

26 Ibid; Shaskol'skii I. Shvedskaia interventsiia... P. 108-112.

27 E. Gorn - Gustavu... P. 52.

28 S. Zholkevskii — Sigizmundu III, Żółkiew, 4.05.1615, 17.05. 1615 // Pisma Stanisława Żółkiewskiego, kanclerza koronnego i hetmana / ed. by A. Bielowski. Lwów, 1861. P. 232, 236.

29 E. Gorn - Gustavu... P. 52; Ia. Kunovskii - E. Gornu, Kałpno (Kalpno), 4.03.1615 // TÜR. F. 6:B. L. 66-69; E. Gorn - Kh. Dembinskomu, Novgorod, 12.03.1615 // Ibid. L. 138-139. 
gentry. It is also easy to understand that this type of operation in war-ravaged region didn't have any chance of success.

It is conceivable that the whole story was a false flag operation inspired by Gosiewski. In this situation the main actor of the plot was lieutenant Kunowski, a Protestant, who at the turn of 1613 was under the patronage of Lithuanian referendary and served in his regiment. Little is known about the early years of his military carrier. Since 1617 he had started to celebrate and praise in poetry all res gestas of his patron and commander. Over the course of two decades he had dedicated 15 of his works to Gosiewski ${ }^{30}$.

So, we do have to ask if Dembiński, about whom we do not presently have any detailed information, Kunowski, Wolski and Plecki with their outfits weren't by chance sent by Gosiewski to the Swedes as some kind of the Trojan horse or poisoned fruit. On the one hand, their service in the army of de la Gardie enabled them to gather information about the developments in Novgorod region on the eve of Swedish-Russian negotiations in Dederino and Stolbova. On the other hand, execution of the terms of the agreement, mentioned earlier, concerning recruitment of 4000 troops from the Commonwealth could have meant financial ruin for Sweden, already being in quite poor state after losing war with Denmark. The consequences were obvious.

Aleksander Gosiewski had an experience in attempting at such clandestine operations in his long political and military carrier. He was, after all, a borderland starosta of Wielizh, Lithuanian referendary and one of closest associates of Great Chancellor Lew Sapieha, and as such was responsible for the operations of Lithuanian intelligence. For example, in 1609 it was his manipulated reports about the situation in Smolensk and at the Lithuanian-Russian border that determined the course of war between the Commonwealth and Russia. The conflict was quite useful for further agenda of the Grand Duchy of Lithuania (especially, for Lew Sapieha) but not exactly for the Kingdom of Poland. Furthermore, in 1611 while serving as commander of Polish-Lithuanian garrison in Moscow, he was involved in the murder of Prokofii Liapunov, one of the leaders of the first militia: he fabricated a letter with a signature and the seal of Liapunov. These were lies that discredited Liapunov. Gosiewski "threw" this letter to the Cossacks who were part of the first militia and hostile to Liapunov. They used it and murdered Liapunov ${ }^{31}$. These issues obviously require further studies.

But we digressed. Going back to the conflict between Dembiński and Horn - Swedish commander rejected claims made by his Polish subordinate and his answer to the threats was the following: "His majesty (Gustav Adolf $-\mathrm{TB}$ ) defeated all of his foes and there were no confederates powerful enough who with God's help couldn't be defeated, so I'll tell you again - "your grace" - I would advise not to risk it because we will be defending ourselves with all our might" 32 .

In May 1615, to avoid escalation of the conflict Moor commanded his men to leave Polish- Lithuanian camp and start establishing a new one, although it is unclear whether he was following Horn's orders in this regard. Left alone, Dembiński's men became easy

${ }^{30}$ Kunowski J. Ekspedycja inflantska 1621 roku / ed. by W.Walczak, K. Łopatecki. Białystok, 2007. S. 26-43.

31 A. Gosevskii - L.Sapege, ze stanowiska między granicą łucką, toropiecką i wieliską, 26.07.1609 // SRA. Skoklostersamlingen. E. 8597. L. 57-59 ob.; A. Gosevskii-Sigizmundu III, z granicy (rubieży) wielkołuckiej, toropieckiej i wieliskiej, 30.07.1609 // Ibid. L. 60; Bohun T. Moskwa 1612 ... S. 147-151.

32 E. Gorn - Kh. Dembinskomu... L. 139. 
targets for the defenders of the city. In the middle of that month they were suddenly attacked and obliterated. Horn noted that the Russians "had captured 50 men, most of the rest were killed and (Polish and Lithuanians - TB) got what they deserved" 33 .

Gustav Adolf tried to capture Pskov once again, but a three-month-siege of the city finally failed in October 1615, and negotiations between the Russians and Swedes began shortly in Dederino and Stolbova. Peace had been brokered by March of 1617.

The Polish and Lithuanian participation in the Swedish war efforts in the early $17^{\text {th }}$ century was, for obvious reasons, very limited. Cultural barriers and military conflicts between Sweden and the Commonwealth were the main obstacles. This had changed at the end of the first decade of the century when the Commonwealth engaged in war with Russia. Its unfavorable development for the-Lithuanian side exacerbated the problem of military confederacies, while at the same time saturated the marketplace of war with mercenary soldiers eager to earn a living. This concerned primarily Ukrainian Cossacks, who had three main ways of making a living: very profitable raids on the shores of the Black Sea against Crimean Tatars and Turks (these were strongly opposed by the Commonwealth), participation in diversions against Russia (on their own or as part of larger operations conducted by Polish-Lithuanian colonels) and, lastly, enlisting in Swedish armed forces of governor Jacob de la Gardie. It is worth noticing that although Cossack outfits led by colonels Sidor and Boryszpolec didn't play a major part in the war, their sheer numbers were notable, at least in the context of the Commonwealth. Their service in the Swedish military units was the logical conclusion of tactics applied by Lithuanian high command, which revolved around relieving the country of demoralized elements and making local arrangements with the governor of Novgorod.

The situation of outfits recruited from Polish-Lithuanian noble men was a little bit different. Mostly, they didn't enlist in the army of de la Gardie because of legal constrictions resulting not only in penalties, but also ostracism from the rest of the "nation of gentry". In the light of this, the fact that outfits under Dembiński, Jaromir Plecki and Stanisław Wolski served in the Swedish army was an unusual occurrence that needs further explanation.

\section{References}

Bohun T. Moskwa 1612. Warszawa, Bellona Publ., 2005. 280 s.

Bohun T. Najemnicy z Wysp Brytyjskich w armii szwedzkiej na początku XVII wieku. Studia $z$ dziejów stosunków Rzeczypospolitej z Państwem Moskiewskim w XVI-XVII wieku. Eds M. Nagielski, K. Bobiatyński, P. Gawron. Zabrze; Tarnowskie Góry, Inforeditions Publ., 2013, ss. 116-147.

Ciara M. Konfederacje wojskowe w Polsce w latach 1590-1610. Studia i Materiały do Historii Wojskowości. T.XXXI. Polska Akademia Nauk. Komitet Nauk Historycznych. Komisja Historii Wojskowej. Wrocław; Warszawa; Kraków, Zakład Narodowy im. Ossolińskich. Wydawnictwo Polskiej Akademii Nauk Publ., 1988, ss. 61-80.

Filipczak-Kocur A. Konfederacja grodzieńska wojska litewskiego w latach 1609-1610. Pamiętnik Biblioteki Kórnickiej. Z.18. Polska Akademia Nauk. Biblioteka Kórnicka. Poznań; Kórnik, Dział Gromadzenia,Wydawnictwa Publ., 1981, ss. 175-198.

Generalstaben. Sveriges krig 1611-1632. Vol.I (Danska och ryska krigen). Stockholm, V. Petersons bokindustriaktiebolag, 1936, $631 \mathrm{~s}$.

Generalstaben. Sveriges krig 1611-1632. Vol. II (Polska kriget). Stockholm, V. Petersons bokindustriaktiebolag, 1936, $617 \mathrm{~s}$.

Kurbatov O. Tikhvinskoe osadnoe sidenie 1613 g. Moscow, Tseikhgauz Publ., 2006, 48 p. (In Russian)

${ }^{33}$ E. Gorn - Gustavu... P. 62 
Łopatecki K. "Disciplina militaris" w wojskach Rzeczypospolitej do połowy XVII wieku. Białystok, Instytut Badań nad Dziedzictwem Kulturowym Europy Press, 2012. 802 s.

Mankell J. Uppgifter rörande svenska krigsmagtens styrka, sammansättning och fördelning sedan slutet af fëmtonhundratalet. Stockholm, C. M. Thimgren Publ., 1865, 602 s.

Michałek A. Konfederacja wojska stołecznego pod regimentem imć Cieklińskiego Józefa. Teki HistoryczneCahiers d'histoire-Historical papers. T.XVI. London, Polskie Towarzystwo Historyczne na Obczyźnie Publ.,1969-1971, ss. 166-210.

Michałek A. Zejście załogi polskiej z Kremla i konfederacja Cieklińskiego 1612-1614. Teki HistoryczneCahiers d'histoire-Historical papers. T.XV. London, Polskie Towarzystwo Historyczne na Obczyźnie Publ., 1966-1968, ss. 113-142.

Shaskol'skii I. Shvedskaia interventsiia v Karelii v nachale XVII v. Petrozavodsk, Gosudarstvennoe izdatel'stvo Karelo-Finskoi SSR, 1950, 168 p. (In Russian)

Skobelkin O. Smuta i sud'by sluzhilykh "nemtsev". Mininskie chteniia. Sbornik nauchnykh trudov po istorii Smutnogo vremeni v Rossii nachala XVII v. V pamiat' 400-letiia Nizhegorodskogo Podviga. Eds A. Kuznetsov, A.Morokhin, O. Naumov. Nizhnii Novgorod, Kvarts Publ., 2012, pp.242-248. (In Russian)

Urwanowicz J. Wojskowe "sejmiki". Koła w wojsku Rzeczypospolitej XVI-XVII wieku. Dissertationes Universitatis Varsoviensis. Białystok, Filia UW w Białymstoku Press, 1996, 265 s.

Wimmer J. Wojsko i skarb Rzeczypospolitej u schyłku XVI i w pierwszej połowie XVII wieku. Studia i Materiały do Historii Wojskowości. T. XIV. Polska Akademia Nauk. Komitet Nauk Historycznych. Komisja Historii Wojskowej. Wrocław; Warszawa; Kraków, Zakład Narodowy im. Ossolińskich, Wydawnictwo Polskiej Akademii Nauk Publ., 1968, ss. 3-91.

Zamiatin G. "K Rossiiskomu tsarstviiu pristoiat". Bor'ba za osvobozhdenie russkikh gorodov, zakhvachennykh shvedami, v 1613-1614 gg. Velikii Novgorod, Sankt-Peterburgskii institut istorii RAN Publ.; Novgorodskii gosudarstvennyi universitet imeni Iaroslava Mudrogo Press, 2012, 209 p. (In Russian)

Zamiatin G. Rossiia i Shvetsiia v nachale XVII veka. Ocherki politicheskoi i voennoi istorii. St. Petersburg, Sankt-Peterburgskii institut istorii RAN Publ.; Yaroslav the Wise Novgorod State University Press; Institut iazyka, literatury i istorii Karel'skogo nauchnogo tsentra RAN; Evropeiskii Dom Publ., 2008, 506 p. (In Russian) 